\title{
Study of Salivary Stress Factor Activity in Patients with Diabetes Mellitus During the Period of Adaptation to Complete Removable Laminar Dentures
}

\author{
Lyubov Leybyuk ${ }^{*}$, Mykola Rozhko, Olena Rozhko
}

\begin{abstract}
Diabetes mellitus is referred to as non-communicable epidemic of the $21^{\text {st }}$ century and the fight against diabetes is one of medical and social challenges. One of its complications is damage to periodontal tissues that is accompanied by tooth loss. Any removable denture is a foreign body being a stress factor for the oral cavity. The objective of the research was to study dynamic changes in the activity of stress factor indicators, namely salivary cortisol, glucose and alpha-amylase levels in diabetic patients after prosthodontic treatment with complete removable laminar dentures.

Materials and Methods. For this study, patients at the age of 45 to 74 years were divided into two groups: Group I included 52 edentulous patients with type 2 diabetes mellitus who were treated with acrylic resin complete removable laminar dentures; Group II comprised 52 edentulous patients without endocrine pathology who were treated with acrylic resin complete removable laminar dentures as well. Saliva served as the study material. The enzyme-linked immunosorbent assay was used to determine salivary cortisol levels. Glucose concentration in saliva was determined by a unified enzymatic method. Alpha-amylase activity was determined by the enzymatic colorimetric method.

Results. According to the research results, before prosthodontic treatment, salivary cortisol levels of patients with diabetes mellitus were 2.4 times higher as compared to patients without somatic pathology. In phase I of adaptation to complete removable laminar dentures, in patients with diabetes mellitus, salivary cortisol concentration increased drastically by 1.4 times as compared to the indicator before prosthodontic treatment $(5.61 \pm 0.83 \mathrm{ng} / \mathrm{ml}$ vs. $4.02 \pm 0.65 \mathrm{ng} / \mathrm{ml}, \mathrm{p}<0.01)$, while in the group of patients without endocrine pathology, cortisol levels increased by 1.2 times; salivary glucose level of patients with diabetes mellitus increased by 1.3 times, while in patients without endocrine pathology, it increased by 1.1 times; in patients of Group I, salivary alpha-amylase levels increased by 1.2 times, while in patients of Group II, salivary alpha-amylase concentration increased by 1.05 times.

Conclusions. In patients with diabetes mellitus, changes in saliva composition indicate a significant reduction in the adaptation mechanisms, that complicates and significantly prolongs the period of adaptation to complete removable laminar dentures.
\end{abstract}

\section{Keywords}

diabetes mellitus; complete removable laminar denture; adaptation; saliva; stress factors

Ivano-Frankivsk National Medical University, Ukraine

*Corresponding author: dental.ukr@gmail.com 


\section{Problem statement and analysis of the latest research}

The endocrine system is the major component of humoral regulation of bodily functions. Specialists in most fields of medicine have to deal with manifestations of endocrine disorders [9].

Diabetes mellitus (DM) is referred to as noncommunicable epidemic of the $21^{\text {st }}$ century and the fight against DM is one of medical and social challenges. DM prevalence rises due to the increasing number of people with genetic predisposition to DM, the increase in an average life expectancy, the intensification of the pace of life, environmental degradation and social deterioration, dietary changes that, in combination with physical inactivity, result in the increasing number of obese people and increased incidence of chronic cardiovascular diseases (hypertension, atherosclerosis) that are considered as risk factors as well. One of diabetic complications is damage to periodontal tissues that is accompanied by complete tooth loss that requires prosthodontic treatment $[1,2,7]$. Any type of dental prostheses, primarily removable one, is a foreign body being a stress factor for the oral cavity. Therefore, the term "adaptation" is closely associated with removable dentures [8]. According to literature, stress is a general non-specific response of the body to stimuli that is characterized by activating the neurohumoral mechanisms and metabolic changes they caused. According to B. Folkov, when defining the term "stress", standard nature of a stress response and its significant role as a necessary component of more complex adaptation process should be emphasized [3]. The effects of stress on the cardiovascular system, the gastrointestinal tract, and the central nervous system have been well-studied; however, its effects on the oral cavity during prosthodontic treatment of diabetic edentulous patients with removable dentures at different stages of adaptation to complete removable laminar dentures (CRLD) and the methods of possible correcting pathological changes in the oral cavity have not been sufficiently studied yet. The oral cavity, and especially the salivary glands, are sensitive to stress due to their close correlation with the neurohumoral mechanisms. Excessive or prolonged activation of the stress response, as well as the lack of the adaptive responses to stress factors may result in various pathological changes in tissues and organs. The biological role of the stress response is to adapt the body to unfavorable factors; however, long-term effect of stress factors leads to maladaptation, i.e., the impaired functions of the physiological systems, structural changes that result in organ diseases, including oral diseases. The stress response is triggered by the activation of the hypothalamic pituitary adrenal (HPA) axis and the sympathoadrenal system that secrete the corresponding hormones (adrenocorticotropic hormone, ketosteroids and catecholamines). Changes in the concentration of cortisol in saliva are used as an indicator of the HPA axis activity; the reference cortisol levels range from 0.2 to $4.4 \mathrm{ng} / \mathrm{ml}$. In recent years, salivary alpha-amylase (sAA) the secretion of which is regulated by beta-adrenergic stimulation has been suggested as a marker of emotional stress. The reference value for sAA is $107 \mathrm{U} / \mathrm{L}$. Glucose level in saliva is considered as one of the stress indicators as well; normal salivary glucose levels are $0.2-0.3 \mathrm{~mol} / \mathrm{l}[3,6]$.

The objective of the research was to study dynamic changes in the indicators of stress factors in saliva of diabetic patients during 3 phases of adaptation to CRLD.

\section{Materials and Methods}

For this study, patients at the age of 45 to 74 years were divided into two groups: Group I included 52 edentulous patients with type 2 diabetes mellitus who were treated with acrylic resin complete removable laminar dentures; Group II comprised 52 edentulous patients without endocrine pathology who were treated with acrylic resin CRLD as well. Saliva served as the study material: unstimulated saliva samples were collected in volumetric tubes by the spitting method for a period of $20 \mathrm{~min}$ in the morning on an empty stomach. The studies were carried out in all the 3 adaptation phases: on the $3^{\text {rd }}$, $7^{\text {th }}$ and $28^{\text {th }}$ days after denture placement.

The enzyme-linked immunosorbent 


\section{Study of Salivary Stress Factor Activity in Patients with Diabetes Mellitus During the Period of Adaptation to Complete Removable Laminar Dentures - 3/7}

assay (ELISA) was used to determine salivary cortisol levels. Glucose concentration in saliva was determined by a unified enzymatic method. AA activity was determined by the enzymatic colorimetric method [4].

For an objective assessment of the reliability degree, the results obtained were statistically processed using widely used methods of variation statistics, the Pentium II PC, statistical software packages Statgraphic 2.3 and Microsoft Excel 2000. The results obtained were statistically processed by calculating the arithmetic mean (M), the standard deviation $(\sigma)$, the standard error $(\mathrm{m})$. A t-test, where $\mathrm{t}$ is a criterion of accuracy, $\mathrm{M}$ is the arithmetic mean, Sx stands for sample standard deviation, was used to determine if there was a significant difference between the means of samples [5].

This study is a fragment of comprehensive research of the Department of Dentistry of the Educational and Research Institute of Postgraduate Education "Clinical and Experimental Substantiation of New Methods for Diagnosis, Prevention and Prosthodontic Treatment (of Dental Diseases) in the Population of Ivano-Frankivsk Region (20172020)". No 0118u 003873.

\section{Results}

The results of the studies conducted are presented in Table 1.

According to the results obtained, before prosthodontic treatment of complete tooth loss, cortisol concentration in saliva of patients with DM was $4.02 \pm 0.65 \mathrm{ng} / \mathrm{ml}$, i.e., the upper reference limit was observed. In patients without DM, before prosthodontic treatment, the average cortisol level was $1.66 \pm 0.34 \mathrm{ng} / \mathrm{ml}$ being 2.4 times lower as compared to patients with endocrine pathology.

In adaptation phase I, the phase of reflex stimulation (on the $3^{\text {rd }}$ day), salivary cortisol concentration in patients of Group I increased drastically by 1.4 times as compared to the indicator before prosthodontic treatment $(5.61 \pm 0.83 \mathrm{ng} / \mathrm{ml} \mathrm{vs}$. $4.02 \pm 0.65 \mathrm{ng} / \mathrm{ml}, \mathrm{p}<0.01)$. On the $7^{\text {th }}$ day of adaptation, the phase of conditioned reflex inhibition, patients with DM presented with a moderate in- crease in salivary cortisol levels up to $6.15 \pm 1.12 \mathrm{ng} / \mathrm{ml}$, that was 1.5 times higher than the initial values, $\mathrm{p}<0.01$. On the $28^{\text {th }}$ day after denture placement, the phase of extinction of conditioned reflex stimuli, cortisol concentration in saliva of patients with DM increased to $6.68 \pm 1.21 \mathrm{ng} / \mathrm{ml}$, that was 1.08 times higher than the indicator obtained on the $7^{\text {th }}$ day, 1.7 times higher than the indicator before obtained prosthodontic treatment and exceeded the upper reference limit by 1.5 times, $\mathrm{p}<0.01$.

In the group of patients without DM, there was observed a more moderate increase in salivary cortisol level in all the phases of adaptation to CRLD. On the $3^{\text {rd }}$ day after denture placement, cortisol levels increased significantly by 1.2 times from $1.66 \pm 0.34 \mathrm{ng} / \mathrm{ml}$ to $2.02 \pm 0.42 \mathrm{ng} / \mathrm{ml}, \mathrm{p}<0.01$. On the $7^{\text {th }}$ day, they increased to $2.33 \pm 0.51 \mathrm{ng} / \mathrm{ml}$, $\mathrm{p}<0.01$. On the $28^{\text {th }}$ day after CRLD placement, salivary concentration of cortisol in patients of Group II was $2.42 \pm 0.63 \mathrm{ng} / \mathrm{ml}$, that was 1.4 times higher than the initial data; however, it did not exceed the reference range for this stress factor. It is worth mentioning that in patients without endocrine pathology, during all the adaptation phases, there were observed significantly lower salivary cortisol levels as compared to patients with DM (Fig. 1).

Before prosthodontic treatment of complete tooth loss with CRLD, salivary glucose level of patients with DM was $0.44 \pm 0.05 \mathrm{~mol} / \mathrm{l}$ exceeding the normal range and that of patients without comorbidity $(0.23 \pm 0.02 \mathrm{~mol} / \mathrm{l})$ by 1.5 and 1.9 times, respectively, $\mathrm{p}<0.01$. In adaptation phase I, on the $3^{\text {rd }}$ day, salivary glucose level of patients with DM increased significantly by 1.3 times to $0.56 \pm 0.07 \mathrm{~mol} / \mathrm{l}, \mathrm{p}<0.01$. On the $7^{\text {th }}$ day, this indicator was $0.65 \pm 0.08 \mathrm{~mol} / \mathrm{l}$, that was 1.5 times higher than the initial values, $\mathrm{p}<0.01$. On the $28^{\text {th }}$ day after CRLD placement, in patients of Group I, the highest glucose concentration in saliva was observed $-0.69 \pm 0.09 \mathrm{~mol} / \mathrm{l}$, that was 1.6 times higher than the indicator obtained before prosthodontic treatment, $\mathrm{p}<0.01$.

In the group of patients without endocrine pathology, in adaptation phase I, the increase in sali- 
Table 1. Indicators of stress factor activity in saliva of patients depending on the period of adaptation to CRLD.

\begin{tabular}{ccccc}
\hline \multirow{2}{*}{ Group } & \multirow{2}{*}{ Adaptation phase } & \multicolumn{3}{c}{ Indicators of stress factors } \\
& Before prosthodontic treatment & $4.02 \pm 0.65^{*}$ & $0.44 \pm 0.05^{*}$ & $96.42 \pm 7.26^{* \mathrm{o}}$ \\
\multirow{3}{*}{ Group I (n=52) } & On the $3^{\text {rd }}$ day & $5.61 \pm 0.83^{* \mathrm{o}}$ & $0.56 \pm 0.07^{* \mathrm{o}}$ & $114.28 \pm 8.63^{* \mathrm{o}}$ \\
& On the $7^{\text {th }}$ day & $6.15 \pm 1.12^{* \mathrm{o}}$ & $0.65 \pm 0.08^{* \mathrm{o}}$ & $126.15 \pm 9.55^{* \mathrm{o}}$ \\
& On the $28^{\text {th }}$ day & $6.68 \pm 1.21^{* \mathrm{o}}$ & $0.69 \pm 0.09^{* \mathrm{o}}$ & $133.38 \pm 9.93^{* \mathrm{o}}$ \\
\hline \multirow{3}{*}{ Group II $(\mathrm{n}=52)$} & Before prosthodontic treatment & $1.66 \pm 0.34^{* \mathrm{o}}$ & $0.23 \pm 0.02^{* \mathrm{o}}$ & $105.23 \pm 8.44^{* \mathrm{o}}$ \\
& On the $3^{\text {rd }}$ day & $2.02 \pm 0.42^{* \mathrm{o}}$ & $0.26 \pm 0.03^{* \mathrm{o}}$ & $110.61 \pm 9.13^{* \mathrm{o}}$ \\
& On the $7^{\text {th }}$ day & $2.33 \pm 0.51^{* \mathrm{o}}$ & $0.31 \pm 0.04^{* \mathrm{o}}$ & $116.39 \pm 9.35^{* \mathrm{o}}$ \\
& On the $28^{\text {th }}$ day & $2.42 \pm 0.63^{* \mathrm{o}}$ & $0.29 \pm 0.04^{* \mathrm{o}}$ & $112.52 \pm 9.54^{* \mathrm{o}}$ \\
\hline
\end{tabular}

Notes:

* - a significant difference between the indicators of Group I and Group II, $\mathrm{p}<0.01$;

- - a significant difference between the indicators before prosthodontic treatment, $\mathrm{p}<0.01$.

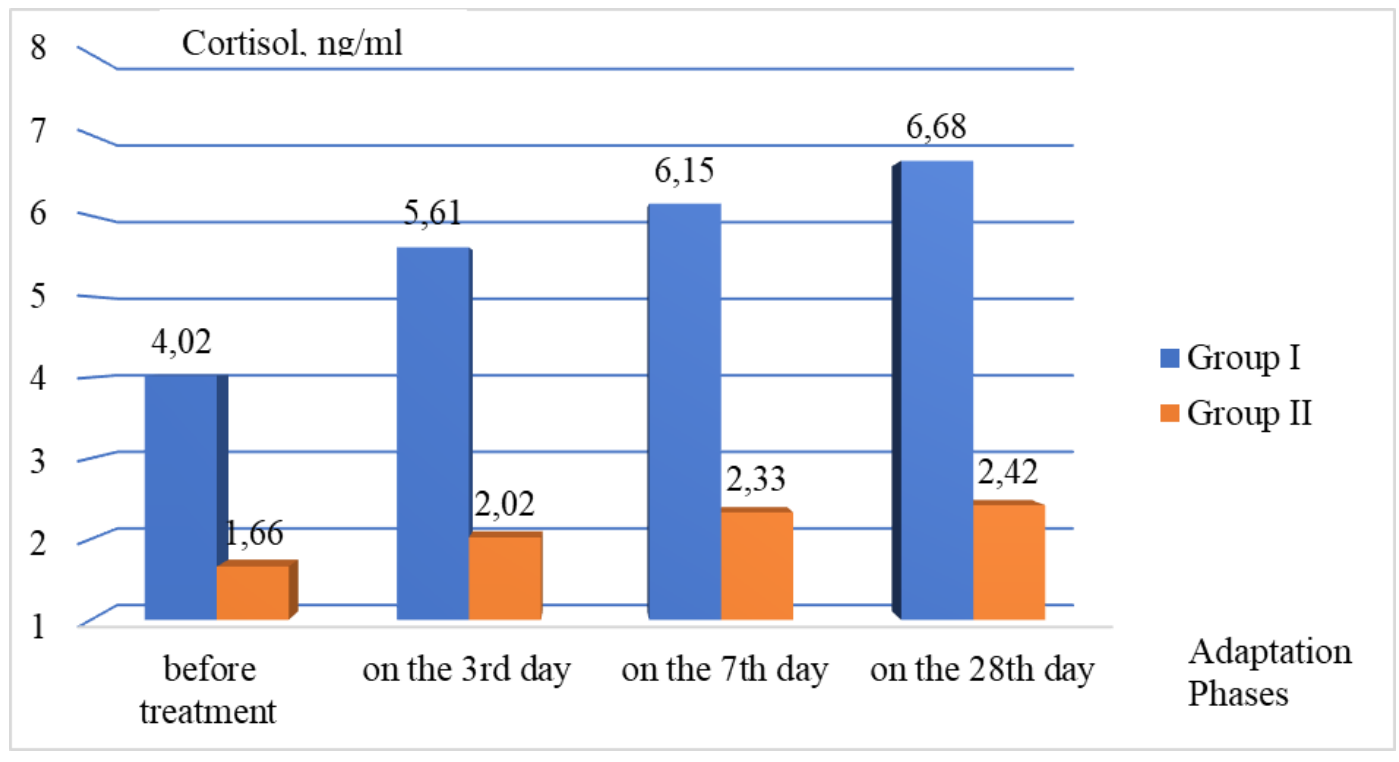

Figure 1. Dynamic changes in salivary cortisol levels of all the patients.

vary glucose level by 1.1 times from $0.23 \pm 0.02$ $\mathrm{mol} / \mathrm{l}$ to $0.26 \pm 0.03 \mathrm{~mol} / \mathrm{l}$ was observed as well, $\mathrm{p}<0.01$. In adaptation phase II, there was observed a moderate increase in salivary glucose level $(0.31 \pm 0.04 \mathrm{~mol} / \mathrm{l})$. However, on the $28^{\text {th }}$ day, in the final adaptation phase, in patients of Group II, the concentration of glucose in saliva decreased to $0.29 \pm 0.04 \mathrm{~mol} / \mathrm{l},(\mathrm{p}<0.01)$ in contrast to patients of Group I, whose glucose levels in saliva continued to increase (Fig. 2).

Dynamic changes in amylolytic activity of all the patients during various adaptation phases are presented in Fig. 3. It is worth mentioning that in patients with DM, before prosthodontic treatment, the level of sAA was $96.42 \pm 7.26 \mathrm{U} / \mathrm{L}$ being 1.1 times lower than normal values, while in patients without endocrine pathology, sAA levels were within normal limits $(105.23 \pm 8.44 \mathrm{U} / \mathrm{L})$ being 1.09 times higher as compared to patients with DM.

In patients with DM, on the $3^{\text {rd }}$ day of removable denture placement, sAA levels increased by 1.2 times to $114.28 \pm 8.63 \mathrm{U} / \mathrm{L}, \mathrm{p}<0.01$. On the $7^{\text {th }}$ day, in adaptation phase II, sAA concentration increased by 1.3 times as compared to the initial val- 


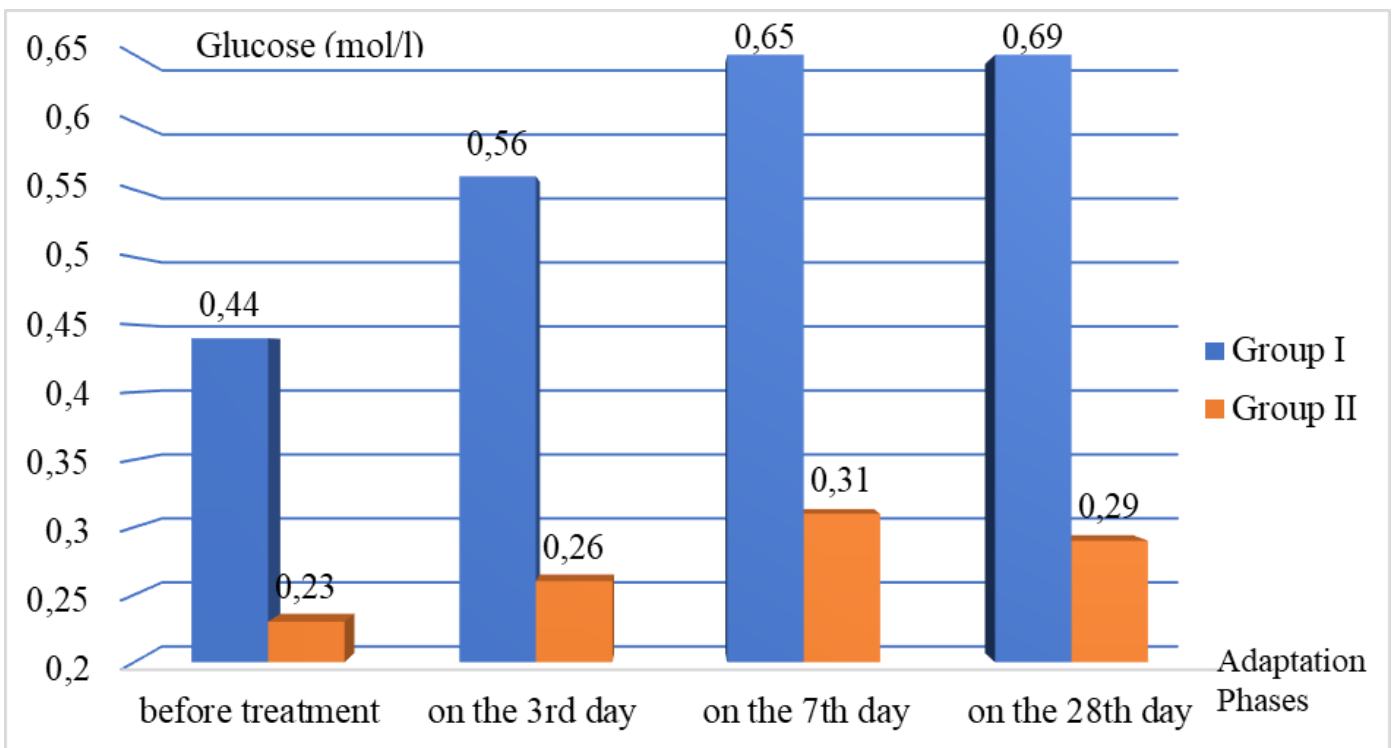

Figure 2. Dynamic changes in salivary glucose levels of all the patients.

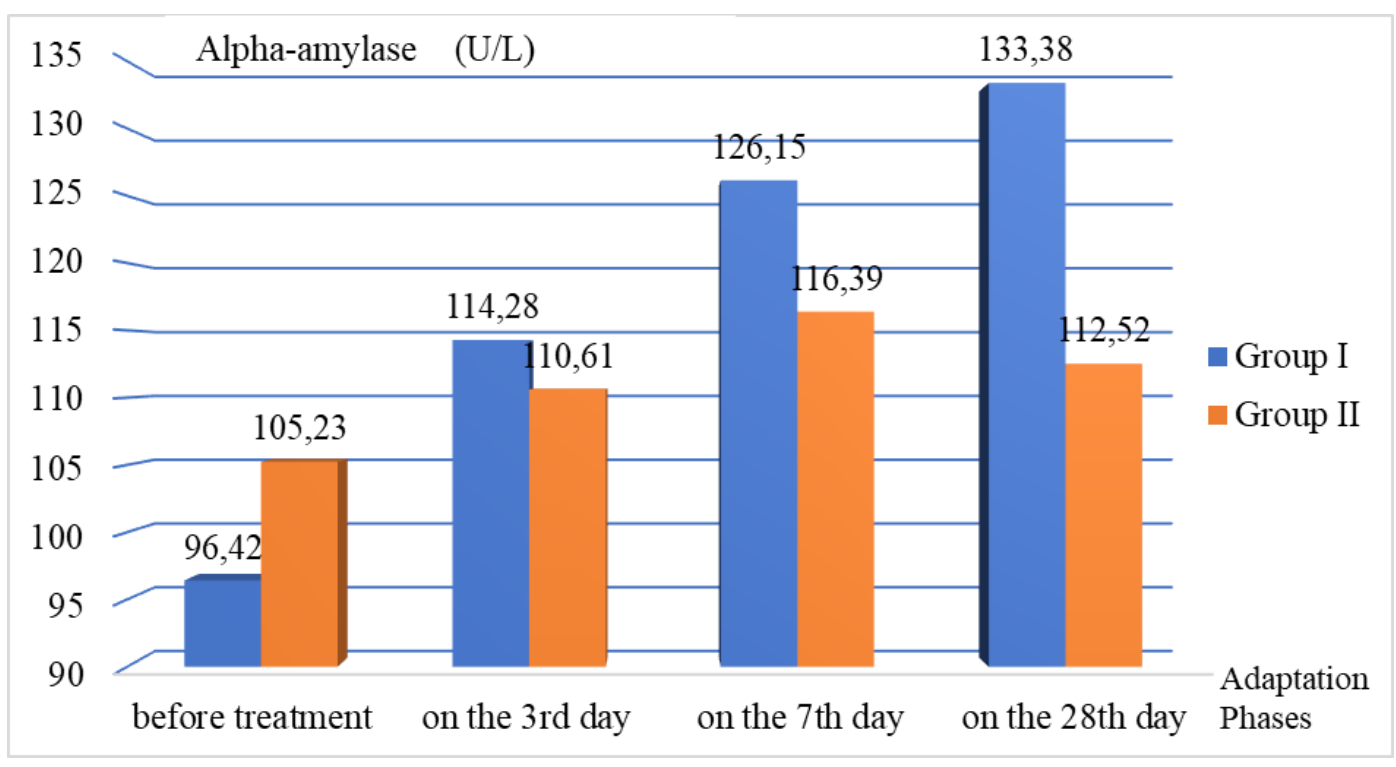

Figure 3. Dynamic changes in sAA levels of all the patients.

ues. On the $28^{\text {th }}$ day, the level of amylolytic activity increased by 1.4 times to $133.38 \pm 9.93 \mathrm{U} / \mathrm{L}$ that might indicate the stress response of the salivary glands to removable dentures in diabetic patients.

In patients of Group II, amylolytic activity increased as well; however, slowly increasing activity was observed. In adaptation phase I, sAA concentration increased by 1.05 times from $105.23 \pm 8.44 \mathrm{U} / \mathrm{L}$ to $110.61 \pm 9.13 \mathrm{U} / \mathrm{L}, \mathrm{p}<0.01$.

In adaptation phase II, this indicator increased to $116.39 \pm 9.35 \mathrm{U} / \mathrm{L}, \mathrm{p}<0.01$. In adaptation phase III, sAA levels of patients without endocrine pathology decreased to $112.52 \pm 9.54 \mathrm{U} / \mathrm{L}$, that was 1.2 times lower than those in patients with DM.

According to the research results, before prosthodontic treatment, salivary cortisol levels of patients with DM were 2.4 times higher as compared to patients without somatic pathology. This indicated impaired regulation in DM, as glucocorticoids affect, directly or indirectly, all the phys- 


\section{Study of Salivary Stress Factor Activity in Patients with Diabetes Mellitus During the Period of Adaptation to Complete Removable Laminar Dentures - 6/7}

iological and biochemical processes in the body. Before prosthodontic treatment of complete tooth loss with CRLD, salivary glucose level of patients with DM was $0.44 \pm 0.05 \mathrm{~mol} / \mathrm{l}$ exceeding the normal range and that of patients without comorbidity $(0.23 \pm 0.02 \mathrm{~mol} / \mathrm{l})$ by 1.5 and 1.9 times, respectively, $\mathrm{p}<0.01$. According to the results obtained, the increase in salivary stress factors of all the patients was found to be the most significant in adaptation phase I, the phase of reflex stimulation. However, in patients with DM, salivary cortisol concentration increased drastically by 1.4 times as compared to the indicator obtained before prosthodontic treatment $(5.61 \pm 0.83 \mathrm{ng} / \mathrm{ml}$ vs. $4.02 \pm 0.65 \mathrm{ng} / \mathrm{ml}$, $\mathrm{p}<0.01$ ), while in the group of patients without endocrine pathology, cortisol levels increased by 1.2 times. On the $3^{\text {rd }}$ day of adaptation to CRLD, salivary glucose level of patients with DM increased by 1.3 times, while in patients without endocrine pathology, it increased by 1.1 times; in patients of Group I, sAA levels increased by 1.2 times, while in patients of Group II, sAA concentration increased by 1.05 times. Adaptation phase II, the phase of conditioned reflex inhibition, was characterized by a more moderate increase in salivary concentration of cortisol, glucose and ptyalin (AA) in all the patients; however, in patients with DM, the indicators of all the salivary stress factors were significantly higher as compared to patients without endocrine pathology.

Adaptation phase III was characterized by the extinction of conditioned reflex stimuli. In patients with DM, a further increase in salivary concentration of cortisol, glucose and AA was observed, that indicated prolonged stress response to CRLD, while in patients without endocrine pathology, only slight increase in salivary cortisol levels and decrease in glucose concentration and amylolytic activity were observed, indicating better adaptation mechanisms in this group of patients.

\section{Discussion}

The study of salivary stress factors in diabetic patients with CRLD revealed that before prosthodontic treatment, their salivary cortisol levels were 2.4 times higher as compared to patients without somatic pathology. This indicated impaired regulation in DM, since glucocorticoids affect, directly or indirectly, all the physiological and biochemical processes in the body. According to the research results, the most significant increase in salivary stress factors in all the patients was observed in adaptation phase I, the phase of reflex stimulation. However, in diabetic patients, salivary cortisol levels increased drastically by 1.4 times as compared to the indicator before prosthodontic treatment $(5.61 \pm 0.83 \mathrm{ng} / \mathrm{ml}$ vs. $4.02 \pm 0.65 \mathrm{ng} / \mathrm{ml}, \mathrm{p}<0.01)$, while in the group of patients without endocrine pathology, salivary cortisol concentration increased by 1.2 times. On the $3^{\text {rd }}$ day of adaptation to CRLD, salivary concentration of glucose in diabetic patients increased by 1.3 times, while in patients without DM, it increased by 1.1 times; in patients of Group I, sAA concentration increased by 1.2 times, while in patients of Group II, sAA levels increased by 1.05 times. Adaptation phase II, the phase of conditioned reflex inhibition, was characterized by a more moderate increase in salivary levels of cortisol, glucose and ptyalin (AA) in all the patients; however, in diabetic patients, the indicators of all the salivary stress factors were significantly higher as compared to patients without endocrine pathology. In adaptation phase III, in patients with DM, a further increase in salivary concentration of cortisol, glucose and AA was observed, that indicated prolonged stress response to CRLD.

The results of this research are consistent with the findings obtained by Riabushko N.O. et al., Tsuber V.Yu. and Van Steregen A $[10,11,12]$.

\section{Conclusions}

Summarizing the data obtained, we can assert that saliva is among the first to respond to stress. In patients with DM, changes in saliva composition indicate a significant reduction in the adaptation mechanisms. Removable denture, as an irritative factor, causes the activation of the sympathetic nervous system, stimulates a significant increase in salivary stress factors that, in patients with DM, complicates and significantly prolongs the period of 


\section{Study of Salivary Stress Factor Activity in Patients with Diabetes Mellitus During the Period of Adaptation to Complete Removable Laminar Dentures - 7/7}

adaptation and reduces the time of effective CRLD use.

\section{Prospects of Further Researches}

We plan to conduct a questionnaire survey of patients with DM who use CRLD to clarify complications arising in prosthodontic treatment with removable dentures. The results of interactive questionnaire survey will be used in the development of preventive and therapeutic strategy to improve the efficacy of prosthodontic treatment with CRLD and prevention of potential complications in patients with DM.

\section{Informed Consent}

Written informed consent was obtained from the patients who participated in this case.

\section{Conflict of Interest}

The authors stated no conflict of interest.

\section{References}

[1] Al-Maskari AY, Al-Maskari MY, Al-Sudairy S. Oral manifestations and complications of diabetes mellitus: a review. Sultan Qaboos University Medical Journal. 2011; 11 (2): 179-186.

[2] Dedov II, Shestakova MV. Sakharnyy diabet: diagnostika, lecheniye, profilaktika. Moscow: Meditsinskoye informatsionnoe agentstvo; c2011. 808p.

[3] Folkov B. Emotsionalnyy stress i ego znacheniye dlya razvitiya serdechnososudistykh zabolevaniy. Kardiologiya. 2007; 10: 4-11.

[4] Goryachkovskiy AM. Klinicheskaya biokhimiya v laboratornoy diagnostike. Odessa: Ekologiya; c2005. 616p.

[5] Lapach SN, Chubenko AV, Babich PN. Osnovnyye printsipy primeneniya statisticheskikh metodov v klinicheskikh ispytaniyakh. Kyiv: Morion; c2012. 160p.
[6] Meyerson FZ, Pshennikova MG. Adaptatsiya $\mathrm{k}$ stressornym situatsiyam i fizicheskim nagruzkam. Moscow: Meditsina. c1988. 256 p.

[7] Pankiv VI. Tsukrovyi diabet: vyznachennia, klasyfikatsiia, epidemiolohiia, faktory ryzyku. International Journal of Endocrinology (Ukraine). 2013; 7 (55): 95-104.

[8] Rozhko MM, Nespriadko VP. Ortopedychna stomatolohiia. Kyiv: Knyha plius; c2003. $552 \mathrm{p}$.

[9] World Health Organization. Available from: https://www. euro.who.int/en/ home

[10] Riabushko N, Dvornik V, Baranova A et al. Changes in a-amylase activity of oral fluid in the process of complex treatment of patients with ischemic heart disease with defects of dentition. Ukrainian Dental Almanac. 2016; 2: 4850. [published in Ukrainian]

[11] Tsuber VYu. Effect of psychoemotional stress on activity of alpha amylase and concentration of total protein in whole saliva of young adults. Actual Problems of the Modern Medicine: Bulletin of Ukrainian Medical Stomatological Academy. 2010; 10 (4): 165-168. [published in Ukrainian].

[12] Van Stegeren A, Rohleder N, Everaerd W, Wolf OT. Salivary alpha amylase as marker for adrenergic activity during stress: effect of betablockade. Psychoendocrinology. 2006; 31: 137-141. DOI: https://doi.org/ $10.1016 / j \cdot p s y n e u e n .2005 .05 .012$ [PMid:16046076]

Received: 2020-08-12

Revised: 2020-08-26

Accepted: 2020-09-02 